\title{
Integrins in T Cell Physiology
}

\author{
Alessandra Bertoni ${ }^{1}$ (D), Oscar Alabiso ${ }^{2}$, Alessandra Silvia Galetto ${ }^{3}$ and Gianluca Baldanzi ${ }^{1, *}$ \\ 1 Department of Translational Medicine and Institute for Research and Cure of Autoimmune Diseases, \\ University of Piemonte Orientale, 28100 Novara, Italy; alessandra.bertoni@med.uniupo.it \\ 2 Department of Translational Medicine, University of Eastern Piedmont, Novara-Italy and Oncology \\ Division, University Hospital “Maggiore della Carità”, 28100 Novara, Italy; oscar.alabiso@med.unipmn.it \\ 3 Department of Translational Medicine, University of Eastern Piedmont, Novara 28100-Italy and Palliative \\ Care Division, A.S.L., 13100 Vercelli, Italy; galetto@med.unipmn.it \\ * Correspondence: gianluca.baldanzi@med.uniupo.it; Tel.: +39-0321-660-527
}

Received: 24 December 2017; Accepted: 2 February 2018; Published: 6 February 2018

\begin{abstract}
From the thymus to the peripheral lymph nodes, integrin-mediated interactions with neighbor cells and the extracellular matrix tune $\mathrm{T}$ cell behavior by organizing cytoskeletal remodeling and modulating receptor signaling. LFA- 1 ( $\alpha$ L $\beta 2$ integrin) and VLA-4 ( $\alpha 4 \beta 1$ integrin) play a key role throughout the $\mathrm{T}$ cell lifecycle from thymocyte differentiation to lymphocyte extravasation and finally play a fundamental role in organizing immune synapse, providing an essential costimulatory signal for the $\mathrm{T}$ cell receptor. Apart from tuning $\mathrm{T}$ cell signaling, integrins also contribute to homing to specific target organs as exemplified by the importance of $\alpha 4 \beta 7$ in maintaining the gut immune system. However, apart from those well-characterized examples, the physiological significance of the other integrin dimers expressed by $\mathrm{T}$ cells is far less understood. Thus, integrin-mediated cell-to-cell and cell-to-matrix interactions during the $\mathrm{T}$ cell lifespan still represent an open field of research.
\end{abstract}

Keywords: adhesion; costimulation; signal 2; tension; cytoskeleton

\section{Introduction}

Integrins act as adhesion receptors playing a pivotal role in the interaction with the extracellular matrix as well as with neighbor cells. Thus, integrins provide mechanical support but also generate a signal that integrates with chemokines and antigens to modulate $\mathrm{T}$ cell motility, proliferation and differentiation. In the present review, we will summarize integrin relevance in $\mathrm{T}$ cell biology by focusing on the best-characterized instances. Readers may instead refer to Reference [1] for a good review describing the cytoskeletal coupling and the control of integrin activity in lymphocytes.

Multiple $\alpha$ and $\beta$ integrin subunits are expressed during the T cell lifecycle with some differences in specific populations. As shown in Figures 1 and 2, expression analysis points to a robust and consistent expression of selected $\alpha$ (mainly $\alpha 4$ and $\alpha \mathrm{L}$ followed by $\alpha 5, \alpha 6, \alpha \mathrm{V}$ and especially in mature $\mathrm{CD}^{+} \alpha \mathrm{E}$ ) and $\beta$ subunits (mainly $\beta 1, \beta 2$ and $\beta 7$ followed by $\beta 3$ ). Those subunits couple to form receptors for the extracellular matrix (fibronectin, laminin, vitronectin) and for ligands expressed on other cells such as vascular cell adhesion molecule 1 (VCAM-1), mucosal addressin cell adhesion molecule 1 (MAdCAM-1) or intercellular cell adhesion molecules (ICAMs). In the latter case, integrins also act as ligands for those surface proteins, activating a signaling cascade in the engaged cells $[2,3]$.

Herein, integrins will be named by their subunits, with the widely used nomenclature based on immunogenicity; their main ligands, according to Humphries et al. [4], are summarized in Table 1. 

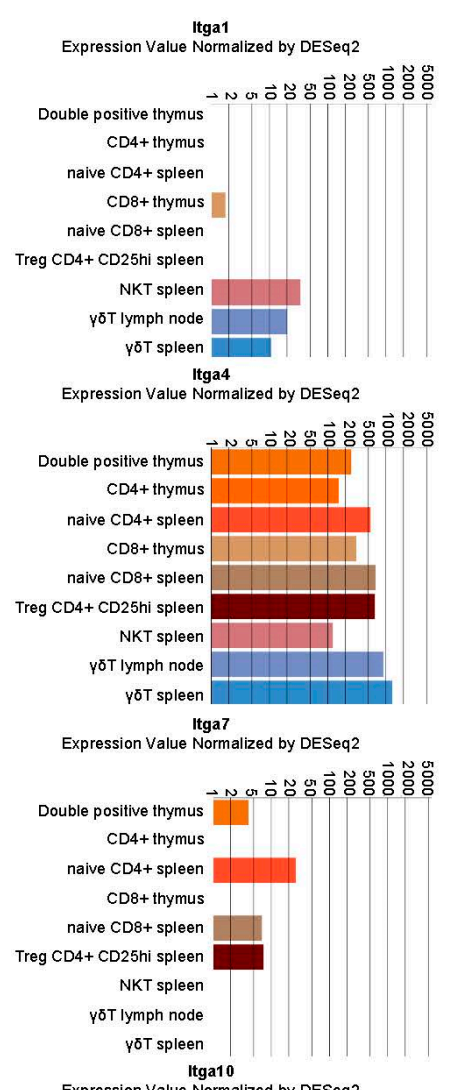

Expression Value Normalized by DESeq2

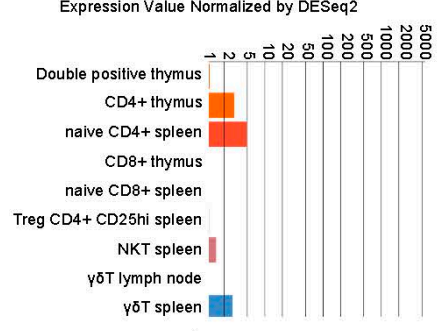

Expression Value Normalized by DESeq2

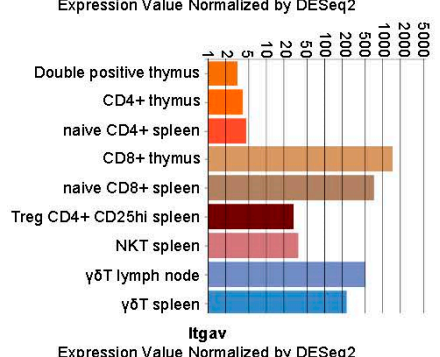

Expression Value Normalized by DESeq2

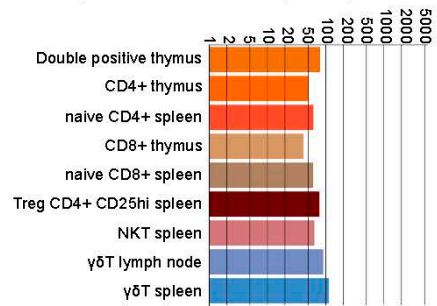

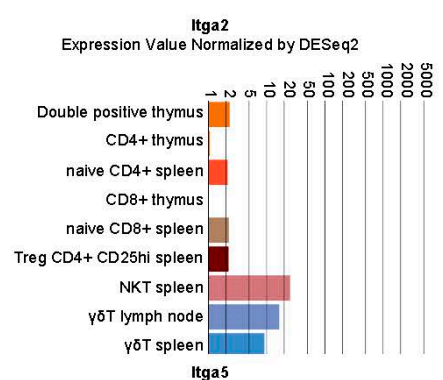

Itga5
Expression Value Normalized by DESeq2

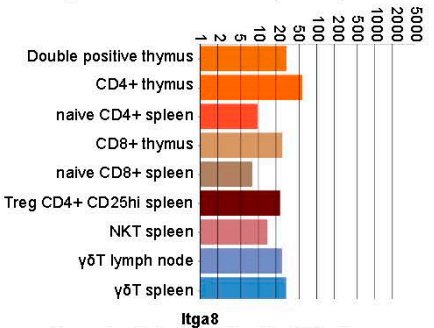

Expression Value Normalized by DESeq2

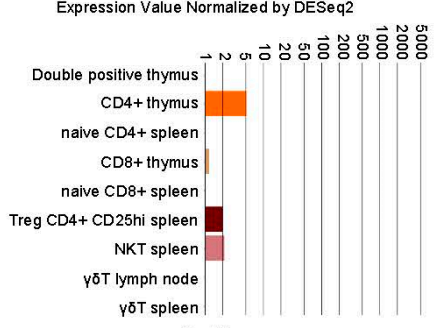

Itga11
Expression Value Normalized by DESeq2

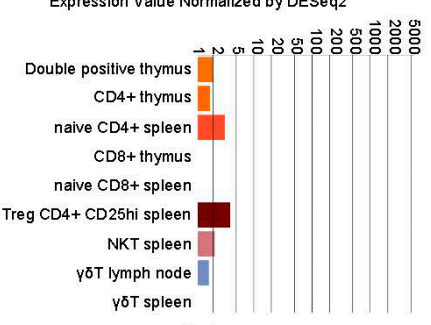

Expression Value Normalized by DESeq2

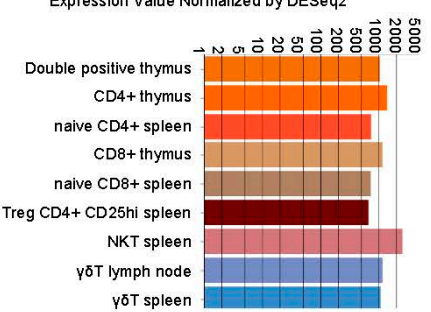

ltgax
Expression Value Normalized by DESeq2

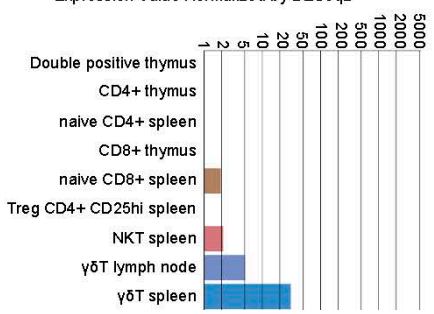

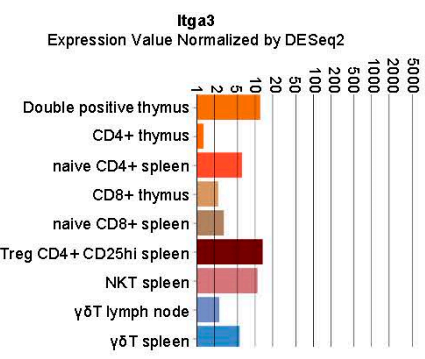

Itga6
Expression Value Normalized by DESeq2

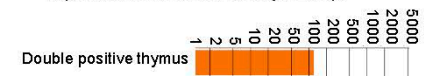

$\mathrm{CD} 4+$ thymus
nave

naive $\mathrm{CD} 4+$ spleen

CD8+ thymus

$+1$

NKT spleen

YठT lymph node

$\mathrm{Y} \delta \mathrm{T}$ spleen

Itga9
Expression Value Normalized by DESeq2

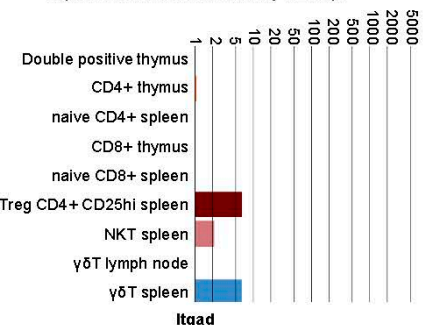

Itgad
Expression Value Normalized by DESeq2

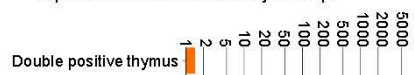

Double pos tive thymus
CD4+ thymus

naive $\mathrm{CD} 4+$ spleen

CD8+ thymus

naive $\mathrm{CD} 8+$ spleen

Treg CD4+CD25hi spleen

NKT spleen

YठT lymph node

Y $\mathrm{T} T$ spleen

Itgam
Expression Value Normalized by DESeq2

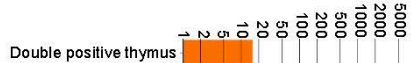

$\mathrm{CD} 4+$ thymus -

naive $\mathrm{CD} 4+$ spleen

$\mathrm{CD} 8+$ thymus

naive CD8+ spleen

Treg CD4+CD25hi spleen

NKT spleen

Y $\delta$ T lymph node

Y̌́T spleen

Figure 1. Integrin $\alpha$ chain expression in selected lymphocyte populations. Data were retrieved by the immunological genome project (Immgem ULI RNAseq database, Geo accession: GSE109125) using the RNA-seq Skyline tool and plotted in global scaling (log10) [5]. Treg: regulatory T cells; NKT: natural killer T cells; $\gamma \delta \mathrm{T}: \gamma \delta \mathrm{T}$ cells. 

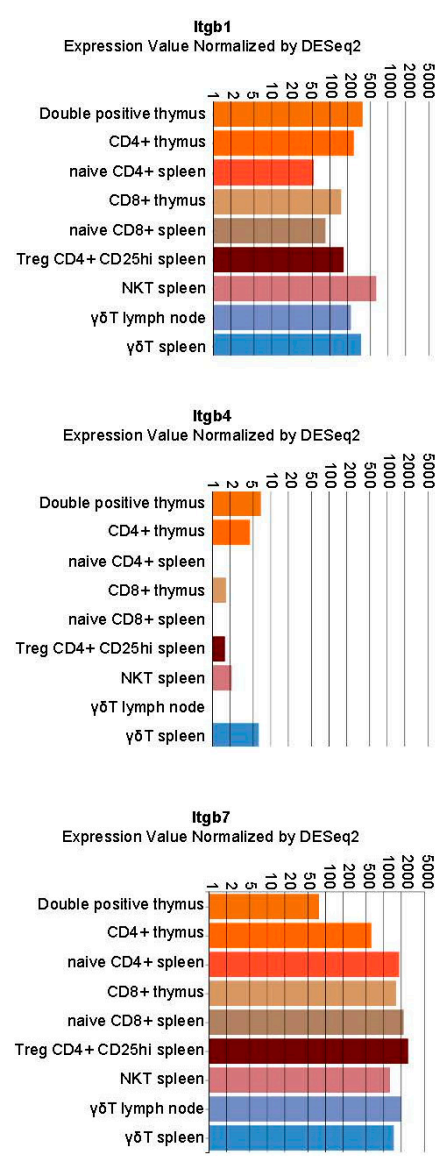
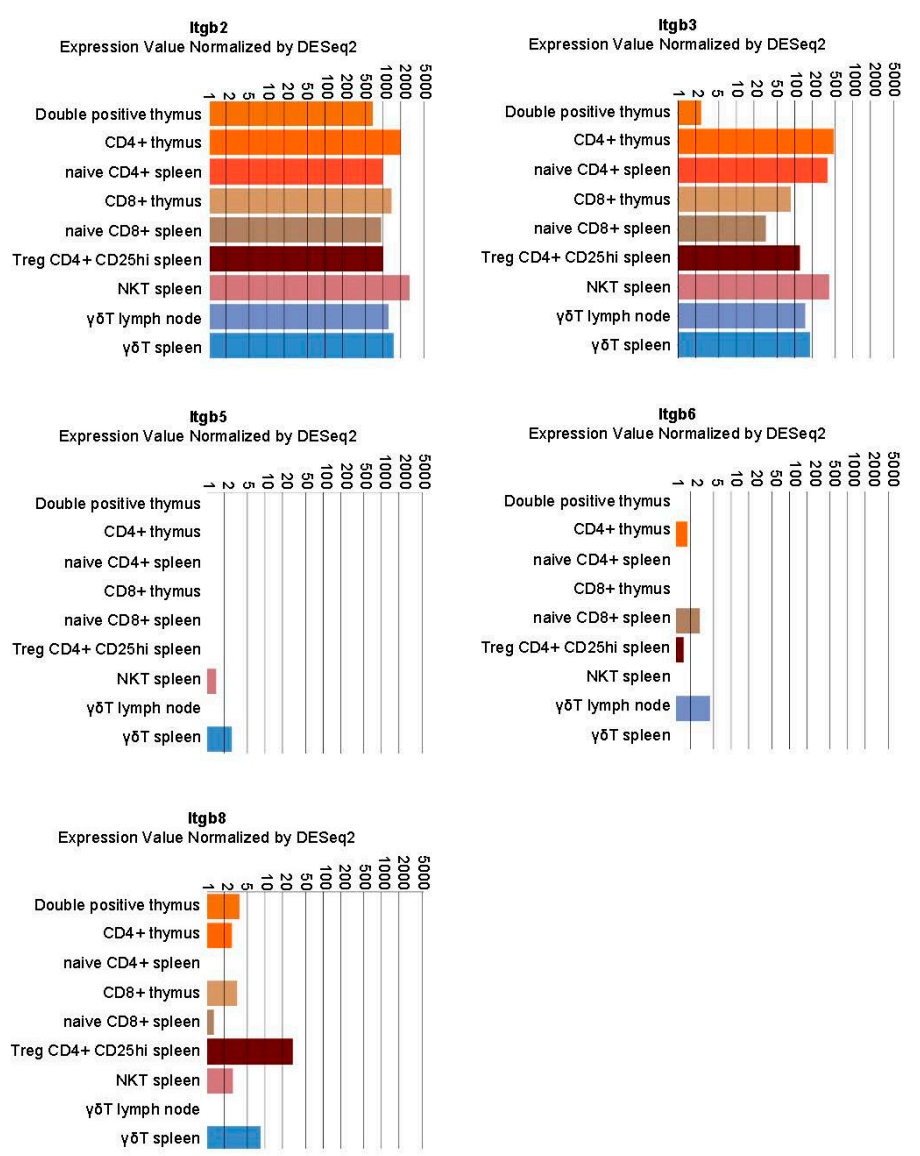

Figure 2. Integrin $\beta$ chain expression in selected lymphocyte populations. Data were retrieved by the immunological genome project (Immgem ULI RNAseq database, Geo accession: GSE109125) using the RNA-seq Skyline tool and plotted in global scaling (log10) [5]. 
Table 1. Integrin heterodimers and their ligands.

\begin{tabular}{|c|c|c|c|c|c|c|c|c|c|c|c|c|c|c|c|c|c|c|c|c|}
\hline \multirow[b]{2}{*}{$\beta$ Subunit } & \multirow[b]{2}{*}{$\alpha$ Subunit } & \multirow[b]{2}{*}{$\begin{array}{l}\text { Alternative } \\
\text { Names }\end{array}$} & \multicolumn{18}{|c|}{ Ligand/Counterreceptors } \\
\hline & & & 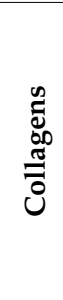 & 墨 & 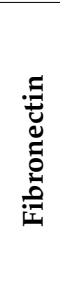 & 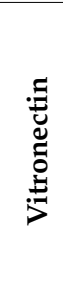 & 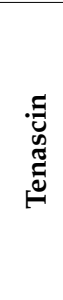 & 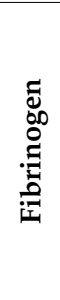 & $\sum_{j}^{J}$ & 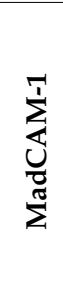 & $\sum_{0}^{\infty}$ & 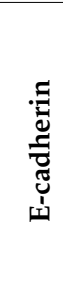 & 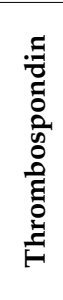 & 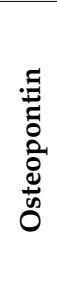 & $\frac{1}{3}$ & 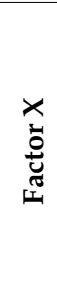 & 仓ी & 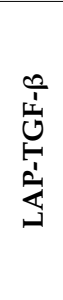 & 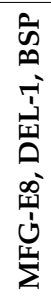 & 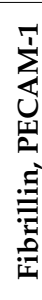 \\
\hline \multirow[t]{12}{*}{$\beta 1$ (ITGB1, CD29) } & $\alpha 1$ (ITGA1, CD49a) & VLA-1 & $\mathrm{x}$ & $\mathrm{x}$ & & & & & & & & & & & & & & & & \\
\hline & $\alpha 2$ (ITGA2, CD49b) & VLA-2 & $x$ & $\mathrm{x}$ & & & & & & & & & $\mathrm{x}$ & & & & & & & \\
\hline & $\alpha 3$ (ITGA3, CD49c) & VLA-3 & & $\mathrm{x}$ & & & & & & & & & $\mathrm{x}$ & & & & & & & \\
\hline & $\alpha 4$ (ITGA4, CD49d) & VLA-4 & & & $\mathrm{x}$ & & & & $\mathrm{x}$ & $\mathrm{x}$ & & & $\mathrm{x}$ & $\mathrm{x}$ & & & & & & \\
\hline & $\alpha 5$ (ITGA5, CD49e) & VLA-5 & & & $\mathrm{x}$ & & & & & & & & & $\mathrm{x}$ & & & & & & \\
\hline & $\alpha 6$ (ITGA6, CD49f) & VLA-6 & & $\mathrm{x}$ & & & & & & & & & & & & & & & & \\
\hline & $\alpha 7$ (ITGA7, CD49g) & & & $\mathrm{x}$ & & & & & & & & & & & & & & & & \\
\hline & $\alpha 8$ (ITGA8, CD49h) & & & & $\mathrm{x}$ & $\mathrm{x}$ & $\mathrm{x}$ & & & & & & & $\mathrm{x}$ & & & & & & \\
\hline & $\alpha 9$ (ITGA9) & & & & & & $\mathrm{x}$ & & $\mathrm{x}$ & & & & & $\mathrm{x}$ & & & & & & \\
\hline & $\alpha 10$ (ITGA10) & & $\mathrm{x}$ & $\mathrm{x}$ & & & & & & & & & & & & & & & & \\
\hline & $\alpha 11$ (ITGA11) & & $\mathrm{x}$ & & & & & & & & & & & & & & & & & \\
\hline & $\alpha_{\mathrm{V}}$ (ITGAV, CD51) & & & $\mathrm{x}$ & $\mathrm{x}$ & $\mathrm{x}$ & & & & & & & & $\mathrm{x}$ & & & & $\mathrm{x}$ & & \\
\hline \multirow[t]{4}{*}{$\beta 2$ (ITGB2, CD18) } & $\alpha \mathrm{D}(\mathrm{ITGAD})$ & & & & & & & & $\mathrm{x}$ & & $\mathrm{x}$ & & & & & & & & & \\
\hline & $\alpha \mathrm{L}$ (ITGAL, CD11a p180) & LFA-1 & & & & & & & & & $\mathrm{x}$ & & & & & & & & & \\
\hline & $\alpha \mathrm{M}$ (ITGAM, CD11b) & Mac-1 & & & & & & $\mathrm{x}$ & & & $\mathrm{x}$ & & & & & $\mathrm{x}$ & $\mathrm{x}$ & & & \\
\hline & $\alpha x($ ITGAX, CD11c) & & $\mathrm{x}$ & & & & & $\mathrm{x}$ & & & $\mathrm{x}$ & & & & & & $\mathrm{x}$ & & & \\
\hline \multirow[t]{2}{*}{$\beta 3$ (ITGB3, CD61) } & $\alpha \mathrm{IIb}($ ITGA2B, CD41) & gpIIb/IIIa & & & $\mathrm{x}$ & $\mathrm{x}$ & & $\mathrm{x}$ & & & & & $\mathrm{x}$ & & $\mathrm{x}$ & & & & & \\
\hline & 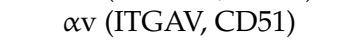 & & & & $\mathrm{x}$ & $\mathrm{x}$ & $\mathrm{x}$ & $\mathrm{x}$ & & & & & $\mathrm{x}$ & $\mathrm{x}$ & $\mathrm{x}$ & & & $\mathrm{x}$ & $\mathrm{x}$ & $\mathrm{x}$ \\
\hline$\beta 4$ (ITGB4) & $\begin{array}{l}\alpha 6 \text { (ITGA6, CD49f) } \\
\alpha \varepsilon \text { (ITGAE, CD107) }\end{array}$ & & & $\mathrm{x}$ & & & & & & & & & & & & & & & & \\
\hline$\beta 5$ (ITGB5) & $\alpha \mathrm{V}$ (ITGAV, CD51) & & & & & $\mathrm{x}$ & & & & & & & & $\mathrm{x}$ & & & & & $\mathrm{x}$ & \\
\hline$\beta 6$ (ITGB6) & $\alpha \mathrm{v}$ (ITGAV, CD51) & & & & $\mathrm{x}$ & & & & & & & & & $\mathrm{x}$ & & & & $x$ & & \\
\hline \multirow[t]{2}{*}{$\beta 7$ (ITGB7) } & $\alpha 4$ (ITGA4, CD49d) & & & & $\mathrm{x}$ & & & & $\mathrm{x}$ & $\mathrm{x}$ & & & & $\mathrm{x}$ & & & & & & \\
\hline & $\alpha \varepsilon$ (ITGAE, CD103) & HML-1 & & & & & & & & & & $\mathrm{x}$ & & & & & & & & \\
\hline$\beta 8$ (ITGB8) & $\alpha \mathrm{v}$ (ITGAV, CD51) & & & & & & & & & & & & & & & & & $\mathrm{x}$ & & \\
\hline
\end{tabular}

Data from [4,6] and from the cited literature. VCAM-1: vascular cell adhesion molecule 1; MadCAM-1: mucosal addressin cell adhesion molecule 1; ICAM-s: intercellular cell adhesion molecule family; vWf: von Willebrand factor; iC3b: inactivated complement component C3b; LAP-TGF- $\beta$ : latency associated peptide transforming growth factor $\beta$; MFG-E8: milk fat globule EGF factor 8; DEL-1: developmental endothelial locus-1; BSP: bone sialoprotein; PECAM-1: platelet endothelial cell adhesion molecule 1; VLA: very late antigen; LFA: lymphocyte function-associated antigen; HML: human mucosal lymphocyte antigen; $x$ : ligand bound. 


\section{Integrins in Thymocyte Differentiation}

$\mathrm{T}$ cell differentiation in the thymus is a multistep process aimed at selecting $\mathrm{T}$ cells endowed with optimal $\mathrm{T}$ cell receptor (TCR) responsiveness to antigens and selectivity toward non-self antigens. Precursor cells from either the fetal liver or the bone marrow give rise to committed CD4 ${ }^{-} / \mathrm{CD} 8^{-}$ double-negative thymocytes, which differentiate into $\mathrm{CD} 4^{+} / \mathrm{CD}^{+}$double-positive cells expressing a stochastically rearranged TCR. Next, immature double-positive cells are positively selected by low-avidity interactions with self-peptide/major histocompatibility complex (MHC) on cortical thymic epithelial cells. Surviving cells mature into $\mathrm{CD} 4^{+}$or $\mathrm{CD} 8^{+}$single-positive $\mathrm{T}$ cells and localize primarily in the medulla, where single positive cells that strongly interact with self-antigens are deleted by negative selection. Thymic differentiation is thus centrally coupled to the TCR maturation and to the resulting signal strength [7]. However, the TCR signaling is finely tuned by integrin-mediated interactions with the stroma cells and a thymus matrix composed mainly of collagen type I and IV, fibronectin, and laminin $[8,9]$. Indeed, thymic differentiation is also coupled to changes in the integrin expression pattern, with $\alpha \mathrm{L} \beta 2$ increasing along with thymocyte maturation and $\alpha 4 \beta 1$ peaking at the double-negative stage [10].

In the thymus, the $\alpha \mathrm{L} \beta 2$ integrin is the lymphocyte integrin superstar, as it is critical for precursor ingress and the generation of common lymphoid progenitors [11]. The subsequent double-negative thymocytes differentiation is dependent on the interaction with the thymic microenvironment. Indeed, it is sustained by $\alpha \mathrm{L} \beta 2$ integrin-binding to thymocyte ICAM- 1 , by $\alpha 4 \beta 1$ binding to VCAM- 1 exposed by cortical stromal cells, and $\alpha 5 \beta 1$ binding to fibronectin produced by medullary stromal cells [12-16]. Conversely, at the later double-positive stage fibronectin primes lymphocytes for activation-induced cell death (AICD) via $\alpha 5 \beta 1$ [17]. This double role of the matrix is not an exception, as laminin $\mathrm{V}$ sustains survival and differentiation of double-negative thymocytes in the cortical area but restrains proliferation of mature thymocytes in the medullary area acting via $\alpha 6 \beta 4[18,19]$.

Thymocyte differentiation is coupled to continuous movement across the thymus zones supported by integrin-mediated adhesion in a maturation stage-dependent manner, thus orchestrating the movement between the thymus cortex and medulla, and the interaction with stromal cells $[20,21]$.

\section{Integrins before Antigen Encounter: From Lymphocyte Migration to T Cell Homing}

Once mature, lymphocytes are prototype migratory cells, actively shuttling between peripheral organs and the immune tissue before establishing contacts with putative antigen-presenting cells (APC). In this flow, integrins play a key role in both supporting $\mathrm{T}$ cell migration and homing to specific target organs.

Chemotactic and proinflammatory chemokines displayed on the endothelial surface drive a severe change in lymphocyte morphology. Spherical-shaped resting T cells become polarized during activation, developing a well-defined cytoplasmic tail. This extremity is designated cellular uropod and is enriched in ICAMs and a CD44 [22,23]. These are the results of a shift from P-selectin-mediated rolling-over endothelial cells to integrin-mediated adhesion (arrest), intraluminal crawling, diapedesis to the extravascular space, and migration along a chemokine gradient in the tissue. Those integrin induced morphological changes are coupled to reorganization of cellular organelles such as the mitochondria, which redistributes to the adhesion zone and later to the uropod [24].

Also in this setting, integrin $\alpha \mathrm{L} \beta 2$ plays a pivotal role, interacting with endothelial ICAM- 1 under the control of chemokines and mechanical forces. Indeed, in naïve unstimulated T cells, $\alpha \mathrm{L} \beta 2$ integrin is predominantly in a default low affinity conformation. Upon encountering endothelial cell-bound chemokines that trigger G-protein-coupled receptor (GPCR) signaling, this latent form of $\alpha \mathrm{L} \beta 2$ is converted into a "primed" extended form possessing an intermediate affinity. In physiologically perfused microvessels, shear force transmitted through the inside attachment to the actin cytoskeleton via talin/kindlin and outside interaction with ICAM-1, promotes adhesion stabilization by integrin transition into a fully active high affinity extended form, supporting T cell arrest on ICAM-1 and production of matrix metalloproteinases [25-27]. 
In vivo, $\alpha \mathrm{L} \beta 2$ affinity down-modulation is crucial in promoting the intravascular crawling and diapedesis of $\mathrm{T}$ cells during homing to peripheral lymph nodes [28]. Likewise, in $\mathrm{T}$ cells laterally migrating on ICAM-1 substrates in vitro, lymphocyte function-associated antigen-1 (LFA-1) affinity is spatiotemporally regulated supporting balanced cycles of adhesion and de-adhesion. There is a shift from an intermediate affinity at the front, to a high affinity focal zone enriched in talin below the cell body, and a low affinity high abundance de-adhesion at the posterior uropod $[29,30]$. This redistribution during migration is coupled to active cycles of chemokine-promoted integrin recycling, which are necessary for migration [31,32].

The pivotal role of $\beta 2$ integrins in leucocyte migration is underscored by the observation that its deficiency in humans causes leukocyte adhesion deficiency type 1 , characterized by recurrent bacterial infections, impaired pus formation, and slow wound healing. Patients show abnormalities in a wide variety of the adhesion-dependent functions of the granulocytes, monocytes, and lymphocytes; and a lack of $\alpha \mathrm{L} \beta 2, \alpha \mathrm{M} \beta 2$, and $\alpha \times \beta 2$ expression [33,34]. In leukocyte adhesion deficiency type 3, mutations in kindlin 3 are observed. Kindlin 3 encodes an intracellular protein that interacts with $\beta$-integrins in hematopoietic cells, thus in those patients the adhesive functions of integrins on both leukocytes and platelets are affected, leading to an immune deficiency resembling leukocyte adhesion deficiency type 1 and Glanzmann thrombasthenia-like bleeding problems [35].

Especially in naïve cells, integrin $\alpha 4 \beta 1$ is important for the rolling of lymphocytes on endothelial cells as well as stalling and extravasation, but it is overcome by $\alpha \mathrm{L} \beta 2$ in activated T cells [36,37]. Like $\alpha \mathrm{L} \beta 2, \alpha 4 \beta 1$ is activated by chemokines into an open conformation and then fully activated upon VCAM-1 binding [38]. However, in lymphocytes migrating in vitro on bi-dimensional surfaces, activated $\alpha 4 \beta 1$ shows a peculiar distribution, accumulating at the leading edge of migrating lymphocytes and colocalizing with chemokine receptors [39]. Additionally, $\alpha 4 \beta 1$ mediated adhesion to VCAM-1 or fibronectin induces expression and release of matrix metalloproteinases -2 and -9 via focal adhesion kinase [40,41].

Effector T cells generated in different lymphoid organs display distinct tissue tropisms, which are regulated by an organ-specific induction of adhesion molecules and chemokine receptors during $\mathrm{T}$ cell priming under the influence of dendritic cells and the local environment [42-44]. Lymphocyte homing to peripheral tissues in vivo is dictated by the interplay of integrin and selectins. Cutaneous effector-memory $\mathrm{T}$ cells express $\mathrm{E}$ - and P-selectin ligands, which appear to be the main players for selective T cell homing into the skin $[45,46]$. On the integrin side, $\alpha 4 \beta 1+$ lymphocytes migrate to multiple extra-intestinal tissues including the skin and also the central nervous system, lungs, and salivary glands, while $\alpha 4 \beta 7+$ lymphocytes preferentially migrate to inflammatory foci in the gut [47-52]. Integrin $\alpha 4 \beta 7$ is selectively induced on T cells and B cells during activation by dendritic cells in gut-associated lymphoid tissues, and allow lymphocytes to bind mucosal addressin cell adhesion molecule-1 (MAdCAM-1). MAdCAM-1 is constitutively expressed on high-endothelial venules of Peyer's patches, mesenteric lymph nodes, and on postcapillary venules in the lamina propria, and its expression is increased at intestinal inflammatory foci [53]. In intestinal Peyer's patches, initial capture from the blood flow is mediated by L-selectin; subsequently, C-C-motif chemokine ligands promote $\alpha 4 \beta 7$-mediated adhesion, converting rolling to arrest and triggering a motile phenotype characterized by lamellipodia and uropod formation [54]. In the intestine, $\mathrm{CD} 8^{+} \mathrm{T}$ cells downregulate $\alpha 4 \beta 7$ and upregulate $\alpha \mathrm{E} \beta 7$ to bind E-cadherin and remain within the intestinal epithelium $[55,56]$.

Due to their multiple biological roles, inhibition of integrin function represents a rational targeted approach in a wide range of human pathologies. Thus, many integrin targeting antibodies were developed and shown to be effective. However, some of them also featured on-target side effects and their development was stopped or the drug withdrawn.

As $\alpha \mathrm{L} \beta 2$ mediates cell-cell as well as cell-matrix interactions involved in innate and adaptive immunity, it plays a relevant role in several diseases. Therefore, several antibodies were developed to interfere with $\alpha \mathrm{L} \beta 2$ functions. Efalizumab is a humanized anti $\alpha \mathrm{L} \beta 2$ used for treatment of plaque psoriasis, however is associated with the development of progressive multifocal 
leukoencephalopathy [57]. Odulimomab is a chimeric IgG1, which targets $\alpha \mathrm{L} \beta 2$ to prevent delayed graft function. Although preclinical studies supported the efficacy of the molecule, its development is terminated [58,59]. Rovelizumab is a humanized anti- $\alpha \mathrm{L}$ antibody used in phase 3 trial for cerebral ischemia. Development appears to have been stopped [60], and the drug was repurposed. Indeed, it showed anti-macrophage function, suggesting that it might be a better therapeutic treatment for post-irradiated tumors [61].

The $\alpha 4$ integrins ( $\alpha 4 \beta 1$ and $\alpha 4 \beta 7$ ) regulate tissue invasion and homing of activated T-cells during inflammation. Blockade of $\alpha 4$-integrins can prevent tissue invasion of the activated T-cell populations driving Multiple Sclerosis [62] and in inflammatory bowel diseases, like Crohn's [63] and ulcerative colitis [64]. Natalizumab is a humanized mouse monoclonal antibody recognizing the human $\alpha 4$ chain in both $\alpha 4 \beta 1$ and $\alpha 4 \beta 7$ integrins $[65,66]$. This antibody is currently used to treat multiple sclerosis and it strongly reduces the numbers of new lesions and relapses [67,68]. Because some patients developed progressive multifocal leukoencephalopathy, the Food and Drug Administration (FDA) allowed its employment only under rigorous monitoring for JC-virus (virus of John Cunningham) [67,69].

\section{Role of Integrins as Costimulatory Molecules: At the Immune Synapse and Beyond}

TCR activation occurs at the immune synapse (IS), a specialized interface between the APC and the T lymphocyte. While sensing MHC-bound antigens by the TCR, the lymphocyte is also engaging the microenvironment consisting of the APC, the surrounding cells, and the extracellular matrix. Integrins play a pivotal role in all of those interactions, thus assisting in setting the threshold for TCR activation and determining its biological outcome.

The best-characterized player is once again the $\alpha \mathrm{L} \beta 2$ integrin (LFA-1) which, by directly engaging intercellular adhesion molecule (ICAM)-family molecules on the APC, is one of the protagonists of the IS organization. In reconstructed in vitro systems, the IS has a well-defined spatial organization, where a set of specialized membrane regions, called "supramolecular activation clusters" (SMACs) are arranged in radial symmetry to form a "bull's eye" shape [70] (Figure 3). The more distal zone (dSMAC) is enriched in CD45 and is characterized by active actin movements resembling the sensory lamellipodia of epithelial cells [71]. Internally, it is possible to distinguish a peripheral zone (pSMAC) enriched in integrins such as $\alpha \mathrm{L} \beta 2$ and also $\alpha 4 \beta 1$, and the associated talin, resembling adhesive lamella [72]. Finally, the central part (cSMAC) is enriched in coactivators (e.g., CD28) and kinases (LCK, Fyn) and is a site of active endocytosis, thus resembling the uropods of migrating cells. The cSMAC is also the secretion site of cytokines, cytolytic agents, and exosomes into the synapse [73].

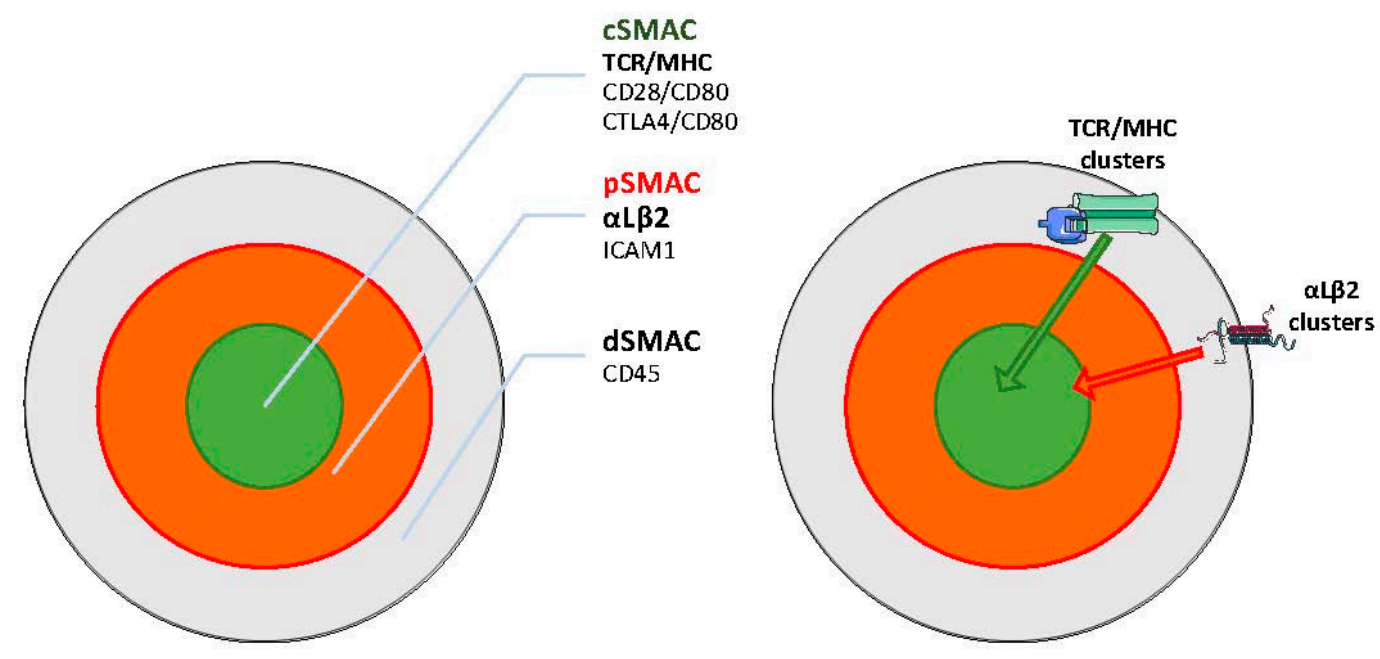

Figure 3. Immune synapse organization. 
Sustained TCR signaling takes place within TCR and integrin microclusters that separately form at the periphery of the synapse and move centripetally, propelled by actin polymerization and myosin IIA contractility [74,75]. Those clusters transduce signals while being transported through the pSMAC. Subsequently, they are differentially sorted because the inward movement of integrin clusters ceased at the pSMAC/cSMAC boundary, while the TCR clusters move further to the cSMAC. Finally, TCR clusters encounter the endocytic sorting machinery at the CSMAC and are internalized, terminating signaling [75]. The centripetal movement of both TCR and $\alpha \mathrm{L} \beta 2$ microclusters is coupled to F-actin assembly and inward flow. At the pSMAC, $\alpha \mathrm{L} \beta 2$ clusters align with actin arcs, whereas TCR microclusters commonly reside between arcs [76]. Antibody labeling experiments indicates that $\alpha \mathrm{L} \beta 2$ extended conformation is enriched throughout the pSMAC region, whereas the open conformation accumulates at the pSMAC-cSMAC boundary sustained by simultaneous ICAM binding and traction by actin cytoskeleton [77]. Accordingly, ICAM is constrained by anchorage at the APC's actin cytoskeleton and this reduced motility is required for efficient $\mathrm{T}$ cell activation [78].

Involvement of integrins in TCR signaling is a very early event with the initial formation of TCR microclusters surrounded and sustained by a micro-adhesion ring containing $\alpha \mathrm{L} \beta 2$ coupled to F-actin [79]. Co-engagement of $\alpha \mathrm{L} \beta 2$ with ICAM is not required for the later formation of the cSMAC region, but increases the accumulation of TCR/MHC complexes within it, and at the same time drives the localization of talin into the PSMAC and the exclusion of CD45 from the synapse [80]. Thus, $\alpha \mathrm{L} \beta 2$ and TCR actively cooperate to drive actin dynamics and cytoskeletal tension generation at the IS, which is essential for full signaling [81]. Indeed, both the TCR and the integrin act as mechanosensors because their signals are enhanced by ligand immobilization on stiff substrates and parallel coupling to the actin cytoskeleton [77]. The outcomes of $\alpha \mathrm{L} \beta 2$ and TCR signaling are also influenced by APC stiffness, with a proportional increase of cytokine release with stiffness, while T cell metabolic properties and cell cycle progression are only increased by high rigidity substrates [82]. Symmetrically, while $\alpha \mathrm{L} \beta 2$ triggering evoke modest mechanic responses by itself, engagement of TCR triggers intense T cell mechanical activity consisting in a sequence of pushing and pulling forces against the APC [83].

This dynamic equilibrium picture of the IS is based mainly on in vitro reconstructed systems with stalled $\mathrm{T}$ cells. In vivo, the presence of antigen induces $\mathrm{T}$ cells to establish brief (i.e., minutes) contacts with multiple APCs, followed by arrested migration and the formation of long-lived (i.e., hours) conjugates with a single APC, which are resolved hours later, allowing the T cells to regain motility and eventually leave the lymph nodes. The stability of such interactions is dictated by the strength of the TCR-antigen-MHC interaction but long lasting interactions also require integrin-mediated adhesion to ICAM-1, and only those interactions promote effector function and $\mathrm{T}$ cell differentiation [84]. Thus, by participating in APC/T cell interactions, $\alpha \mathrm{L} \beta 2$ increases adhesion to the APC and decreases the amount of antigen necessary for $\mathrm{T}$ cell activation $[85,86]$. When $\mathrm{T}$ cells are allowed to move, the IS organization is deeply different: TCR microclusters flow in alignment with cell movement toward an actin-poor sink region [87], while integrin-enriched pSMAC relocates toward the direction of movement [88]. Naive CD8 ${ }^{+} \mathrm{T}$ cells reserve a significant intracellular pool of $\alpha \mathrm{L} \beta 2$ in the uropod during migration that quickly translocates to the cell surface upon antigenic stimulation. Importantly, the redistribution of intracellular LFA-1 on contact with APC is maintained during cell division and leads to an unequal inheritance of LFA-1 in daughter T cells, influencing their behavior [89].

The integrin action at the immune synapse is instructed by the TCR as in resting T cells; $\alpha \mathrm{L} \beta 2$ is maintained in an inactive bent conformation with very low ligand binding capacity. TCR engagement by a high affinity agonist rapidly enhances $\alpha \mathrm{L} \beta 2$ affinity to ICAM- 1 via inside-out signaling mediated by the WAVE2-ARP2/3 (Wiskott-Aldrich syndrome family verprolin-homologous protein 2/actin-related protein-2/3)-dependent F-actin nucleation and the recruitment of talin and kindling 3, promoting integrin activation as well as their clustering $[90,91]$. This results in a progressive $\alpha \mathrm{L} \beta 2$ switch to an intermediate and then high affinity conformation while traveling from the d-SMAC through the p-SMAC, and in a parallel organization of ICAM-1 [77]. Noteworthy, 
the inside-out signaling from the TCR not only plays a role in the immune synapse but also promotes lymphocyte adhesion to matrix proteins such as fibronectin and laminin [92]. In a parallel way, the co-activator function of $\alpha \mathrm{L} \beta 2$ integrin does not require its activation at the immune synapse, as a third cell presenting ICAM-1 can induce a "remote" costimulation [93]. This spatially segregated integrin signal is sufficient to promote talin recruitment and acting remodeling, but does not alter microtubules organizing center reorientation toward the true immune synapse where TCR is active [94]. Altogether those observations suggest an interplay during $\mathrm{T}$ cell activation among the IS, neighbor cells, and the extracellular matrix. Indeed, there are indications of purely TCR-driven migration of $\mathrm{CD}^{+}$lymphocytes to transplanted tissues upon antigen presentation by endothelial cells and APC in local vessels, leading to antigen- and IL-2-directed proliferation outside the lymph node $[95,96]$.

At the biological level, $\alpha \mathrm{L} \beta 2$ engagement with ICAM-1 provides a peculiar type of signal 2, which does not evoke a proliferative response by itself but sustains and complements TCR-induced tyrosine phosphorylation, phosphatidylinositol-specific phospholipase- $\gamma 1$ (PLC- $\gamma 1$ ) activation, and calcium signaling, as well as phosphatidylinositol-3-kinase (PI3K) activity [97-100] . This differs from the prototype co-activator $\mathrm{CD} 28$ which, from the cSMAC, reduces the number of engaged TCRs required for full activation and is also able to prevent anergy [85]. Indeed, both CD28 and $\alpha \mathrm{L} \beta 2$ integrin cooperate to enhance interleukin 2 (IL-2) synthesis but through distinct signaling pathways $[85,100]$. The physiological consequences of the costimulatory signal provided by $\alpha \mathrm{L} \beta 2$ integrins are functions of T cells and range from sustaining cell migration to supporting TCR signaling, with a specific involvement in the generation of the memory cell compartment $[15,101]$. In resting CD4 ${ }^{+}$ $\mathrm{T}$ cells, ICAMs are costimulatory molecules enhancing priming and TCR responsiveness $[86,102,103]$. The response to ICAM- 1 is even stronger in $\mathrm{CD}^{+}$cells, providing costimulatory signals driving proliferation and IL-2 synthesis, but not cell survival [104,105]. Similarly, $\alpha$ L $\beta 2$ plays a pivotal role in $\mathrm{CD}^{+}$engagement and directs the lysis of target cells, and its absence cannot be compensated by increased TCR signaling [106,107].

$\alpha 4 \beta 1$ can act as a costimulatory receptor for $\mathrm{CD} 4^{+} \mathrm{T}$ cells, promoting the synthesis of both IL- 2 and IL-2 receptors, thus promoting proliferation [108]. In addition, $\alpha 4 \beta 1$ is recruited to antigen-dependent immune synapses when the antigen-presenting cell is a B lymphocyte or dendritic cell, colocalizing with $\alpha \mathrm{L} \beta 2$ at the pSMAC. Its engagement promotes polarization toward a T helper 1 response [72].

While the engagement of TCR on naive T lymphocytes results in the proliferation and production of proinflammatory cytokines, the restimulation of activated $\mathrm{T}$ lymphocytes leads to activation-induced cell death (AICD) [109]. In this context, the costimulation of TCR and either $\alpha \mathrm{L} \beta 2$ or $\alpha 4 \beta 1$ increases the AICD of chronically stimulated $\mathrm{CD}^{+} \mathrm{T}$ cells and substantially differs from the effects of CD28, that suppresses apoptosis and promotes cell proliferation [102]. Furthermore, $\alpha \mathrm{L} \beta 2$ is specifically necessary for staphylococcal enterotoxin superantigens-induced $\mathrm{CD} 4^{+}$stimulation as well as for their AICD [110]. In line with this, the $\mathrm{CD}^{+}$blockade of integrin signaling with RGD peptides decreases proximal TCR signaling, and results in decreased FAS ligand expression and the inhibition of AICD. This also happens when triggered by immobilized anti-CD3 antibodies in the absence of APC [111]. It should be noted that matrix binding does not always reinforce AICD, as there are reports of collagen signaling through $\alpha 2 \beta 1$ as well as $\beta 1$ agonist antibodies, inhibiting AICD by inhibiting Fas ligand expression $[112,113]$. Similarly, osteopontin, a matrix protein with the capacity to act also as a proinflammatory cytokine, downmodulates AICD by binding to both $\beta 3$ integrins and CD44 [114].

\section{Matrix Adhesion as a Costimulation}

In line with the role of integrins as costimulatory molecules, several integrins can support TCR-induced T cell activation by binding extracellular matrix proteins, as well as proteins exposed by neighbor cells. Indeed, resting $\mathrm{CD}^{+}$and $\mathrm{CD} 8^{+} \mathrm{T}$ cells are potently costimulated by immobilized fibronectin and laminin, but not by collagen. In contrast, antigen-stimulated $\mathrm{CD} 4^{+}$and $\mathrm{CD} 8^{+} \mathrm{T}$ cells are more potently costimulated by collagen type I than fibronectin. Those responses are $\beta 1$ integrin-dependent and mediated largely by $\alpha 1 \beta 1 / \alpha 2 \beta 1$ for collagen binding [115,116], $\alpha 4 \beta 1 / \alpha 5 \beta 1$ 
for fibronectin binding [117,118], and $\alpha 6 \beta 1$ for laminin binding [119]. Similarly, in differentiated cytotoxic T lymphocytes, $\alpha \mathrm{v} \beta 3$ (vitronectin receptor) is activated by a signal from the TCR to mediate adhesion to fibronectin or vitronectin, and delivers a costimulatory signal for degranulation [120]. Interestingly, fibronectin must be on the same surface as alloantigen to augment the degranulation response, and a specific surface fibronectin splicing variant is synthesized by the activated $\mathrm{T}$ cell itself [121]. When T cells are activated with anti-CD3 coated beads, surface fibronectin, together with the ganglioside GM1, converge at the contact zone where it plays its costimulatory role [122].

It must be noted that proteins present in plasma and serum (such as fibronectin and osteopontin) provide a "hidden" costimulation in many in vitro experiments with lymphocytes. In the absence of serum, engagement of the TCR leads to the induction of Fas, but not to measurable IL-2 secretion or apoptosis. The addition of individual extracellular matrix proteins, including vitronectin, fibronectin, or fibrinogen, restores IL-2 secretion and apoptosis, whereas the addition of osteopontin or entactin is somewhat less effective at recovering IL-2 secretion and does not lead to the induction of apoptosis. Those activations are induced by costimulation via integrin $\alpha V \beta 3$ [123]. Conversely, the extracellular matrix protein tenascin antagonizes not only the fibronectin costimulatory signal in T cells but acts as a generally immunosuppressive extracellular matrix protein, which potentially interferes with TCR-mediated lymphocyte activation [124].

Adding further complexity, some matrix proteins can bind to integrins and to other receptors at the same time. Thrombospondin (TSP)- 1 is a trimeric calcium-binding protein which has been reported to modulate $\mathrm{T}$ cell behavior both positively and negatively. These opposing responses arise from the interactions of TSP1 with multiple receptors such as integrins, CD47, low-density lipoprotein receptor-related protein 1 (LRP1) and calreticulin [125,126]. The integrin $\alpha 4 \beta 1$ is required for the stimulation of $\mathrm{T}$ cell adhesion, chemotaxis, and the matrix metalloproteinase gene expression by TSP1. A second TSP1 receptor, CD47, is not required for some stimulatory responses to TSP1 but plays a significant role because of its TCR antagonistic and anti-proliferative activities [127]. Similarly, osteopontin's action as a pro-inflammatory cytokine is the combined effect of the following: (1) an RGD sequence for binding to $\alpha v \beta 1, \alpha v \beta 3, \alpha v \beta 5, \alpha v \beta 6, \alpha 8 \beta 1$, and $\alpha 5 \beta 1$ integrins and (2) a cryptic SVVYGLR sequence which is exposed upon thrombin cleavage and promotes binding to $\alpha 9 \beta 1, \alpha 4 \beta 1$, and $\alpha 4 \beta 7$ integrins, and (3) a heparin/CD44 binding site [114,128].

\section{Conclusions}

A large body of research has shed light on the contribution of individual integrins on $\mathrm{T}$ cell interactions with the microenvironment. Those studies have revealed a high degree of redundancy and robustness, sensitive only to major perturbations such as the deficiency of an entire integrin class (i.e., leukocyte adhesion deficiency type (1) or their disengagement by actin cytoskeleton (i.e., leukocyte adhesion deficiency type (3). Those complex multistep processes represent an appealing challenge for modelling $[129,130]$. Although in their early stages, these system biology approaches hold the promise of relating the multiple interactions of a cell with its environment to the variety of possible biological outcomes, and represent an exciting new way to explore the complexity of biological systems.

Acknowledgments: This research is original and has a financial support of the Università del Piemonte Orientale. GB is supported by the by the Fondazione Telethon (GGP16252) and TIPSO grant from Regione Piemonte (PAR FSC 2007-2013 Asse I-Innovazione e transizione produttiva-Linea di azione 3: "Competitività industria e artigianato" linea d-Bando regionale sulle malattie Autoimmuni e Allergiche).

Conflicts of Interest: The authors declare no conflict of interest.

\section{References}

1. Hogg, N.; Patzak, I.; Willenbrock, F. The insider's guide to leukocyte integrin signalling and function. Nat. Rev. Immunol. 2011, 11, 416-426. [CrossRef] [PubMed] 
2. Marchese, M.E.; Berdnikovs, S.; Cook-Mills, J.M. Distinct sites within the vascular cell adhesion molecule-1 (VCAM-1) cytoplasmic domain regulate VCAM-1 activation of calcium fluxes versus Rac1 during leukocyte transendothelial migration. Biochemistry 2012, 51, 8235-8246. [CrossRef] [PubMed]

3. Greenwood, J.; Amos, C.L.; Walters, C.E.; Couraud, P.O.; Lyck, R.; Engelhardt, B.; Adamson, P. Intracellular domain of brain endothelial intercellular adhesion molecule-1 is essential for T lymphocyte-mediated signaling and migration. J. Immunol. 2003, 171, 2099-2108. [CrossRef] [PubMed]

4. Humphries, J.D.; Byron, A.; Humphries, M.J. Integrin ligands at a glance. J. Cell Sci. 2006, 119, $3901-3903$. [CrossRef] [PubMed]

5. Shay, T.; Kang, J. Immunological Genome Project and systems immunology. Trends Immunol. 2013, 34, 602-609. [CrossRef] [PubMed]

6. Niu, G.; Chen, X. Why integrin as a primary target for imaging and therapy. Theranostics 2011, 1, 30-47. [CrossRef] [PubMed]

7. Khailaie, S.; Robert, P.A.; Toker, A.; Huehn, J.; Meyer-Hermann, M. A signal integration model of thymic selection and natural regulatory T cell commitment. J. Immunol. 2014, 193, 5983-5996. [CrossRef] [PubMed]

8. Savino, W.; Mendes-Da-Cruz, D.A.; Smaniotto, S.; Silva-Monteiro, E.; Villa-Verde, D.M. Molecular mechanisms governing thymocyte migration: Combined role of chemokines and extracellular matrix. J. Leukoc. Biol. 2004, 75, 951-961. [CrossRef] [PubMed]

9. Choi, Y.I.; Duke-Cohan, J.S.; Chen, W.; Liu, B.; Rossy, J.; Tabarin, T.; Ju, L.; Gui, J.; Gaus, K.; Zhu, C.; et al. Dynamic control of $\beta 1$ integrin adhesion by the plexinD1-sema3E axis. Proc. Natl. Acad. Sci. USA 2014, 111, 379-384. [CrossRef] [PubMed]

10. Sawada, M.; Nagamine, J.; Takeda, K.; Utsumi, K.; Kosugi, A.; Tatsumi, Y.; Hamaoka, T.; Miyake, K.; Nakajima, K.; Watanabe, T. Expression of VLA-4 on thymocytes. Maturation stage-associated transition and its correlation with their capacity to adhere to thymic stromal cells. J. Immunol. 1992, 149, 3517-3524. [PubMed]

11. Bose, T.O.; Colpitts, S.L.; Pham, Q.M.; Puddington, L.; Lefrançois, L. CD11a is essential for normal development of hematopoietic intermediates. J. Immunol. 2014, 193, 2863-2872. [CrossRef] [PubMed]

12. Utsumi, K.; Sawada, M.; Narumiya, S.; Nagamine, J.; Sakata, T.; Iwagami, S.; Kita, Y.; Teraoka, H.; Hirano, H.; Ogata, M. Adhesion of immature thymocytes to thymic stromal cells through fibronectin molecules and its significance for the induction of thymocyte differentiation. Proc. Natl. Acad. Sci. USA 1991, 88, 5685-5689. [CrossRef] [PubMed]

13. Salomon, D.R.; Crisa, L.; Mojcik, C.F.; Ishii, J.K.; Klier, G.; Shevach, E.M. Vascular cell adhesion molecule-1 is expressed by cortical thymic epithelial cells and mediates thymocyte adhesion. Implications for the function of alpha4beta1 (VLA4) integrin in T-cell development. Blood 1997, 89, 2461-2471. [PubMed]

14. Linhares-Lacerda, L.; Ribeiro-Alves, M.; Nogueira, A.C.; Mendes-da-Cruz, D.A.; Magalhães, D.A.; Dardenne, M.; Passos, G.A.; Savino, W. RNA interference-mediated knockdown of CD49e ( $\alpha 5$ integrin chain) in human thymic epithelial cells modulates the expression of multiple genes and decreases thymocyte adhesion. BMC Genom. 2010, 11 (Suppl. 5), S2. [CrossRef] [PubMed]

15. Gottrand, G.; Courau, T.; Thomas-Vaslin, V.; Prevel, N.; Vazquez, T.; Ruocco, M.G.; Lambrecht, B.; Bellier, B.; Colombo, B.M.; Klatzmann, D. Regulatory T-cell development and function are impaired in mice lacking membrane expression of full length intercellular adhesion molecule-1. Immunology 2015, 146, 657-670. [CrossRef] [PubMed]

16. Paessens, L.C.; Singh, S.K.; Fernandes, R.J.; van Kooyk, Y. Vascular cell adhesion molecule-1 (VCAM-1) and intercellular adhesion molecule-1 (ICAM-1) provide co-stimulation in positive selection along with survival of selected thymocytes. Mol. Immunol. 2008, 45, 42-48. [CrossRef] [PubMed]

17. Takayama, E.; Kina, T.; Katsura, Y.; Tadakuma, T. Enhancement of activation-induced cell death by fibronectin in murine $\mathrm{CD}^{+} \mathrm{CD}^{+}$thymocytes. Immunology 1998, 95, 553-558. [CrossRef] [PubMed]

18. Vivinus-Nebot, M.; Ticchioni, M.; Mary, F.; Hofman, P.; Quaranta, V.; Rousselle, P.; Bernard, A. Laminin 5 in the human thymus: Control of T cell proliferation via alpha6beta4 integrins. J. Cell Biol. 1999, 144, 563-574. [CrossRef] [PubMed]

19. Kim, M.G.; Lee, G.; Lee, S.K.; Lolkema, M.; Yim, J.; Hong, S.H.; Schwartz, R.H. Epithelial cell-specific laminin 5 is required for survival of early thymocytes. J. Immunol. 2000, 165, 192-201. [CrossRef] [PubMed] 
20. Prockop, S.E.; Palencia, S.; Ryan, C.M.; Gordon, K.; Gray, D.; Petrie, H.T. Stromal cells provide the matrix for migration of early lymphoid progenitors through the thymic cortex. J. Immunol. 2002, 169, 4354-4361. [CrossRef] [PubMed]

21. Ueda, Y.; Katagiri, K.; Tomiyama, T.; Yasuda, K.; Habiro, K.; Katakai, T.; Ikehara, S.; Matsumoto, M.; Kinashi, T. Mst1 regulates integrin-dependent thymocyte trafficking and antigen recognition in the thymus. Nat. Commun. 2012, 3, 1098. [CrossRef] [PubMed]

22. Del Pozo, M.A.; Sánchez-Mateos, P.; Nieto, M.; Sánchez-Madrid, F. Chemokines regulate cellular polarization and adhesion receptor redistribution during lymphocyte interaction with endothelium and extracellular matrix. Involvement of cAMP signaling pathway. J. Cell Biol. 1995, 131, 495-508. [CrossRef] [PubMed]

23. Del Pozo, M.A.; Cabañas, C.; Montoya, M.C.; Ager, A.; Sánchez-Mateos, P.; Sánchez-Madrid, F. ICAMs redistributed by chemokines to cellular uropods as a mechanism for recruitment of T lymphocytes. J. Cell Biol. 1997, 137, 493-508. [CrossRef] [PubMed]

24. Morlino, G.; Barreiro, O.; Baixauli, F.; Robles-Valero, J.; González-Granado, J.M.; Villa-Bellosta, R.; Cuenca, J.; Sánchez-Sorzano, C.O.; Veiga, E.; Martín-Cófreces, N.B.; et al. Miro-1 links mitochondria and microtubule Dynein motors to control lymphocyte migration and polarity. Mol. Cell. Biol. 2014, 34, 1412-1426. [CrossRef] [PubMed]

25. Shulman, Z.; Shinder, V.; Klein, E.; Grabovsky, V.; Yeger, O.; Geron, E.; Montresor, A.; Bolomini-Vittori, M.; Feigelson, S.W.; Kirchhausen, T.; et al. Lymphocyte crawling and transendothelial migration require chemokine triggering of high-affinity LFA-1 integrin. Immunity 2009, 30, 384-396. [CrossRef] [PubMed]

26. Nordenfelt, P.; Elliott, H.L.; Springer, T.A. Coordinated integrin activation by actin-dependent force during T-cell migration. Nat. Commun. 2016, 7, 13119. [CrossRef] [PubMed]

27. Aoudjit, F.; Potworowski, E.F.; St-Pierre, Y. Bi-directional induction of matrix metalloproteinase-9 and tissue inhibitor of matrix metalloproteinase-1 during T lymphoma/endothelial cell contact: Implication of ICAM-1. J. Immunol. 1998, 160, 2967-2973. [PubMed]

28. Park, E.J.; Peixoto, A.; Imai, Y.; Goodarzi, A.; Cheng, G.; Carman, C.V.; von Andrian, U.H.; Shimaoka, M. Distinct roles for LFA-1 affinity regulation during T-cell adhesion, diapedesis, and interstitial migration in lymph nodes. Blood 2010, 115, 1572-1581. [CrossRef] [PubMed]

29. Stanley, P.; Smith, A.; McDowall, A.; Nicol, A.; Zicha, D.; Hogg, N. Intermediate-affinity LFA-1 binds alpha-actinin-1 to control migration at the leading edge of the T cell. EMBO J. 2008, 27, 62-75. [CrossRef] [PubMed]

30. Smith, A.; Carrasco, Y.R.; Stanley, P.; Kieffer, N.; Batista, F.D.; Hogg, N. A talin-dependent LFA-1 focal zone is formed by rapidly migrating T lymphocytes. J. Cell Biol. 2005, 170, 141-151. [CrossRef] [PubMed]

31. Svensson, L.; Stanley, P.; Willenbrock, F.; Hogg, N. The G $\alpha q / 11$ proteins contribute to T lymphocyte migration by promoting turnover of integrin LFA-1 through recycling. PLoS ONE 2012, 7, e38517. [CrossRef] [PubMed]

32. Stanley, P.; Tooze, S.; Hogg, N. A role for Rap2 in recycling the extended conformation of LFA-1 during T cell migration. Biol. Open 2012, 1, 1161-1168. [CrossRef] [PubMed]

33. López Rodríguez, C.; Nueda, A.; Grospierre, B.; Sánchez-Madrid, F.; Fischer, A.; Springer, T.A.; Corbí, A.L. Characterization of two new CD18 alleles causing severe leukocyte adhesion deficiency. Eur. J. Immunol. 1993, 23, 2792-2798. [CrossRef] [PubMed]

34. Springer, T.A.; Thompson, W.S.; Miller, L.J.; Schmalstieg, F.C.; Anderson, D.C. Inherited deficiency of the Mac-1, LFA-1, p150,95 glycoprotein family and its molecular basis. J. Exp. Med. 1984, 160, 1901-1918. [CrossRef] [PubMed]

35. Svensson, L.; Howarth, K.; McDowall, A.; Patzak, I.; Evans, R.; Ussar, S.; Moser, M.; Metin, A.; Fried, M.; Tomlinson, I.; et al. Leukocyte adhesion deficiency-III is caused by mutations in KINDLIN3 affecting integrin activation. Nat. Med. 2009, 15, 306-312. [CrossRef] [PubMed]

36. Van Kooyk, Y.; van de Wiel-van Kemenade, E.; Weder, P.; Huijbens, R.J.; Figdor, C.G. Lymphocyte function-associated antigen 1 dominates very late antigen 4 in binding of activated T cells to endothelium. J. Exp. Med. 1993, 177, 185-190. [CrossRef] [PubMed]

37. Issekutz, A.C.; Issekutz, T.B. The role of E-selectin, P-selectin, and very late activation antigen-4 in T lymphocyte migration to dermal inflammation. J. Immunol. 2002, 168, 1934-1939. [CrossRef] [PubMed]

38. Sosa-Costa, A.; Isern de Val, S.; Sevilla-Movilla, S.; Borgman, K.J.; Manzo, C.; Teixidó, J.; Garcia-Parajo, M.F. Lateral Mobility and Nanoscale Spatial Arrangement of Chemokine-activated $\alpha 4 \beta 1$ Integrins on T Cells. J. Biol. Chem. 2016, 291, 21053-21062. [CrossRef] [PubMed] 
39. Hyun, Y.M.; Chung, H.L.; McGrath, J.L.; Waugh, R.E.; Kim, M. Activated integrin VLA-4 localizes to the lamellipodia and mediates T cell migration on VCAM-1. J. Immunol. 2009, 183, 359-369. [CrossRef] [PubMed]

40. Yakubenko, V.P.; Lobb, R.R.; Plow, E.F.; Ugarova, T.P. Differential induction of gelatinase B (MMP-9) and gelatinase A (MMP-2) in T lymphocytes upon alpha(4)beta(1)-mediated adhesion to VCAM-1 and the CS-1 peptide of fibronectin. Exp. Cell Res. 2000, 260, 73-84. [CrossRef] [PubMed]

41. Segarra, M.; Vilardell, C.; Matsumoto, K.; Esparza, J.; Lozano, E.; Serra-Pages, C.; Urbano-Márquez, A.; Yamada, K.M.; Cid, M.C. Dual function of focal adhesion kinase in regulating integrin-induced MMP-2 and MMP-9 release by human T lymphoid cells. FASEB J. 2005, 19, 1875-1877. [CrossRef] [PubMed]

42. Campbell, D.J.; Butcher, E.C. Rapid acquisition of tissue-specific homing phenotypes by CD4(+) T cells activated in cutaneous or mucosal lymphoid tissues. J. Exp. Med. 2002, 195, 135-141. [CrossRef] [PubMed]

43. Ferguson, A.R.; Engelhard, V.H. CD8 T cells activated in distinct lymphoid organs differentially express adhesion proteins and coexpress multiple chemokine receptors. J. Immunol. 2010, 184, 4079-4086. [CrossRef] [PubMed]

44. Siewert, C.; Menning, A.; Dudda, J.; Siegmund, K.; Lauer, U.; Floess, S.; Campbell, D.J.; Hamann, A.; Huehn, J. Induction of organ-selective $\mathrm{CD}^{+}{ }^{+}$regulatory T cell homing. Eur. J. Immunol. 2007, 37, 978-989. [CrossRef] [PubMed]

45. Hirata, T.; Furie, B.C.; Furie, B. P-, E-, and L-selectin mediate migration of activated CD8 ${ }^{+}$T lymphocytes into inflamed skin. J. Immunol. 2002, 169, 4307-4313. [CrossRef] [PubMed]

46. Tietz, W.; Allemand, Y.; Borges, E.; von Laer, D.; Hallmann, R.; Vestweber, D.; Hamann, A. CD4 ${ }^{+}$T cells migrate into inflamed skin only if they express ligands for E- and P-selectin. J. Immunol. 1998, 161, 963-970. [PubMed]

47. Woyciechowski, S.; Hofmann, M.; Pircher, H. $\alpha 4 \beta 1$ integrin promotes accumulation of tissue-resident memory CD8(+) T cells in salivary glands. Eur. J. Immunol. 2017, 47, 244-250. [CrossRef] [PubMed]

48. Koni, P.A.; Joshi, S.K.; Temann, U.A.; Olson, D.; Burkly, L.; Flavell, R.A. Conditional vascular cell adhesion molecule 1 deletion in mice: Impaired lymphocyte migration to bone marrow. J. Exp. Med. 2001, 193, 741-754. [CrossRef] [PubMed]

49. Briskin, M.; Winsor-Hines, D.; Shyjan, A.; Cochran, N.; Bloom, S.; Wilson, J.; McEvoy, L.M.; Butcher, E.C.; Kassam, N.; Mackay, C.R.; et al. Human mucosal addressin cell adhesion molecule-1 is preferentially expressed in intestinal tract and associated lymphoid tissue. Am. J. Pathol. 1997, 151, 97-110. [PubMed]

50. Martin-Blondel, G.; Pignolet, B.; Tietz, S.; Yshii, L.; Gebauer, C.; Perinat, T.; Van Weddingen, I.; Blatti, C.; Engelhardt, B.; Liblau, R. Migration of encephalitogenic CD8 T cells into the central nervous system is dependent on the $\alpha 4 \beta 1$-integrin. Eur. J. Immunol. 2015, 45, 3302-3312. [CrossRef] [PubMed]

51. Wolber, F.M.; Curtis, J.L.; Mály, P.; Kelly, R.J.; Smith, P.; Yednock, T.A.; Lowe, J.B.; Stoolman, L.M. Endothelial selectins and alpha4 integrins regulate independent pathways of Tlymphocyte recruitment in the pulmonary immune response. J. Immunol. 1998, 161, 4396-4403. [PubMed]

52. Bauer, M.; Brakebusch, C.; Coisne, C.; Sixt, M.; Wekerle, H.; Engelhardt, B.; Fässler, R. Beta1 integrins differentially control extravasation of inflammatory cell subsets into the CNS during autoimmunity. Proc. Natl. Acad. Sci. USA 2009, 106, 1920-1925. [CrossRef] [PubMed]

53. Mora, J.R.; Bono, M.R.; Manjunath, N.; Weninger, W.; Cavanagh, L.L.; Rosemblatt, M.; Von Andrian, U.H. Selective imprinting of gut-homing T cells by Peyer's patch dendritic cells. Nature 2003, 424, 88-93. [CrossRef] [PubMed]

54. Miles, A.; Liaskou, E.; Eksteen, B.; Lalor, P.F.; Adams, D.H. CCL25 and CCL28 promote alpha4 beta7-integrin-dependent adhesion of lymphocytes to MAdCAM-1 under shear flow. Am. J. Physiol. Gastrointest. Liver Physiol. 2008, 294, G1257-G1267. [CrossRef] [PubMed]

55. Cepek, K.L.; Shaw, S.K.; Parker, C.M.; Russell, G.J.; Morrow, J.S.; Rimm, D.L.; Brenner, M.B. Adhesion between epithelial cells and T lymphocytes mediated by E-cadherin and the alpha E beta 7 integrin. Nature 1994, 372, 190-193. [CrossRef] [PubMed]

56. Zhang, N.; Bevan, M.J. Transforming growth factor- $\beta$ signaling controls the formation and maintenance of gut-resident memory T cells by regulating migration and retention. Immunity 2013, 39, 687-696. [CrossRef] [PubMed]

57. Seminara, N.M.; Gelfand, J.M. Assessing long-term drug safety: Lessons (re) learned from raptiva. Semin. Cutan. Med. Surg. 2010, 29, 16-19. [CrossRef] [PubMed] 
58. Zimmerer, J.M.; Horne, P.H.; Fiessinger, L.A.; Fisher, M.G.; Jayashankar, K.; Garcia, S.F.; Abdel-Rasoul, M.; van Rooijen, N.; Bumgardner, G.L. Inhibition of recall responses through complementary therapies targeting CD8 ${ }^{+}$T-cell- and alloantibody-dependent allocytotoxicity in sensitized transplant recipients. Cell Transplant. 2013, 22, 1157-1169. [CrossRef] [PubMed]

59. Tredget, E.B.; Arefanian, H.; Gill, R.G.; Rajotte, R.V.; Rayat, G.R. Monotherapy with anti-LFA-1 monoclonal antibody promotes long-term survival of rat islet xenografts. Cell Transplant. 2008, 17, 599-608. [CrossRef] [PubMed]

60. Jones, R. Rovelizumab (ICOS Corp). IDrugs 2000, 3, 442-446. [PubMed]

61. Qualls, J.E.; Murray, P.J. A double agent in cancer: Stopping macrophages wounds tumors. Nat. Med. 2010, 16, 863-864. [CrossRef] [PubMed]

62. Viglietta, V.; Baecher-Allan, C.; Weiner, H.L.; Hafler, D.A. Loss of functional suppression by CD4+CD25+ regulatory T cells in patients with multiple sclerosis. J. Exp. Med. 2004, 199, 971-979. [CrossRef] [PubMed]

63. Elices, M.J.; Osborn, L.; Takada, Y.; Crouse, C.; Luhowskyj, S.; Hemler, M.E.; Lobb, R.R. VCAM-1 on activated endothelium interacts with the leukocyte integrin VLA-4 at a site distinct from the VLA-4/fibronectin binding site. Cell 1990, 60, 577-584. [CrossRef]

64. Makker, J.; Hommes, D.W. Etrolizumab for ulcerative colitis: The new kid on the block? Expert Opin. Biol. Ther. 2016, 16, 567-572. [CrossRef] [PubMed]

65. Léger, O.J.; Yednock, T.A.; Tanner, L.; Horner, H.C.; Hines, D.K.; Keen, S.; Saldanha, J.; Jones, S.T.; Fritz, L.C.; Bendig, M.M. Humanization of a mouse antibody against human alpha-4 integrin: A potential therapeutic for the treatment of multiple sclerosis. Hum. Antib. 1997, 8, 3-16.

66. Kent, S.J.; Karlik, S.J.; Cannon, C.; Hines, D.K.; Yednock, T.A.; Fritz, L.C.; Horner, H.C. A monoclonal antibody to alpha 4 integrin suppresses and reverses active experimental allergic encephalomyelitis. J. Neuroimmunol. 1995, 58, 1-10. [CrossRef]

67. Miller, D.H.; Khan, O.A.; Sheremata, W.A.; Blumhardt, L.D.; Rice, G.P.; Libonati, M.A.; Willmer-Hulme, A.J.; Dalton, C.M.; Miszkiel, K.A.; O'Connor, P.W.; et al. A controlled trial of natalizumab for relapsing multiple sclerosis. N. Engl. J. Med. 2003, 348, 15-23. [CrossRef] [PubMed]

68. Polman, C.H.; O'Connor, P.W.; Havrdova, E.; Hutchinson, M.; Kappos, L.; Miller, D.H.; Phillips, J.T.; Lublin, F.D.; Giovannoni, G.; Wajgt, A.; et al. A randomized, placebo-controlled trial of natalizumab for relapsing multiple sclerosis. N. Engl. J. Med. 2006, 354, 899-910. [CrossRef] [PubMed]

69. Langer-Gould, A.; Atlas, S.W.; Green, A.J.; Bollen, A.W.; Pelletier, D. Progressive multifocal leukoencephalopathy in a patient treated with natalizumab. N. Engl. J. Med. 2005, 353, 375-381. [CrossRef] [PubMed]

70. Monks, C.R.; Freiberg, B.A.; Kupfer, H.; Sciaky, N.; Kupfer, A. Three-dimensional segregation of supramolecular activation clusters in T cells. Nature 1998, 395, 82-86. [CrossRef] [PubMed]

71. Dustin, M.L.; Chakraborty, A.K.; Shaw, A.S. Understanding the structure and function of the immunological synapse. Cold Spring Harb. Perspect. Biol. 2010, 2, a002311. [CrossRef] [PubMed]

72. Mittelbrunn, M.; Molina, A.; Escribese, M.M.; Yáñez-Mó, M.; Escudero, E.; Ursa, A.; Tejedor, R.; Mampaso, F.; Sánchez-Madrid, F. VLA-4 integrin concentrates at the peripheral supramolecular activation complex of the immune synapse and drives T helper 1 responses. Proc. Natl. Acad. Sci. USA 2004, 101, 11058-11063. [CrossRef] [PubMed]

73. Dustin, M.L. The immunological synapse. Cancer Immunol. Res. 2014, 2, 1023-1033. [CrossRef] [PubMed]

74. Yi, J.; Wu, X.S.; Crites, T.; Hammer, J.A. Actin retrograde flow and actomyosin II arc contraction drive receptor cluster dynamics at the immunological synapse in Jurkat T cells. Mol. Biol. Cell 2012, 23, 834-852. [CrossRef] [PubMed]

75. Kaizuka, Y.; Douglass, A.D.; Varma, R.; Dustin, M.L.; Vale, R.D. Mechanisms for segregating T cell receptor and adhesion molecules during immunological synapse formation in Jurkat T cells. Proc. Natl. Acad. Sci. USA 2007, 104, 20296-20301. [CrossRef] [PubMed]

76. Murugesan, S.; Hong, J.; Yi, J.; Li, D.; Beach, J.R.; Shao, L.; Meinhardt, J.; Madison, G.; Wu, X.; Betzig, E.; et al. Formin-generated actomyosin arcs propel $\mathrm{T}$ cell receptor microcluster movement at the immune synapse. J. Cell Biol. 2016, 215, 383-399. [CrossRef] [PubMed]

77. Comrie, W.A.; Babich, A.; Burkhardt, J.K. F-actin flow drives affinity maturation and spatial organization of LFA-1 at the immunological synapse. J. Cell Biol. 2015, 208, 475-491. [CrossRef] [PubMed] 
78. Comrie, W.A.; Li, S.; Boyle, S.; Burkhardt, J.K. The dendritic cell cytoskeleton promotes T cell adhesion and activation by constraining ICAM-1 mobility. J. Cell Biol. 2015, 208, 457-473. [CrossRef] [PubMed]

79. Hashimoto-Tane, A.; Sakuma, M.; Ike, H.; Yokosuka, T.; Kimura, Y.; Ohara, O.; Saito, T. Micro-adhesion rings surrounding TCR microclusters are essential for T cell activation. J. Exp. Med. 2016, 213, 1609-1625. [CrossRef] [PubMed]

80. Graf, B.; Bushnell, T.; Miller, J. LFA-1-mediated T cell costimulation through increased localization of $\mathrm{TCR} /$ class II complexes to the central supramolecular activation cluster and exclusion of CD45 from the immunological synapse. J. Immunol. 2007, 179, 1616-1624. [CrossRef] [PubMed]

81. Tabdanov, E.; Gondarenko, S.; Kumari, S.; Liapis, A.; Dustin, M.L.; Sheetz, M.P.; Kam, L.C.; Iskratsch, T. Micropatterning of TCR and LFA-1 ligands reveals complementary effects on cytoskeleton mechanics in T cells. Integr. Biol. 2015, 7, 1272-1284. [CrossRef] [PubMed]

82. Saitakis, M.; Dogniaux, S.; Goudot, C.; Bufi, N.; Asnacios, S.; Maurin, M.; Randriamampita, C.; Asnacios, A.; Hivroz, C. Different TCR-induced T lymphocyte responses are potentiated by stiffness with variable sensitivity. eLife 2017, 6, e23190. [CrossRef] [PubMed]

83. Husson, J.; Chemin, K.; Bohineust, A.; Hivroz, C.; Henry, N. Force generation upon T cell receptor engagement. PLoS ONE 2011, 6, e19680. [CrossRef] [PubMed]

84. Scholer, A.; Hugues, S.; Boissonnas, A.; Fetler, L.; Amigorena, S. Intercellular adhesion molecule-1-dependent stable interactions between T cells and dendritic cells determine CD8 ${ }^{+} \mathrm{T}$ cell memory. Immunity 2008, 28, 258-270. [CrossRef] [PubMed]

85. Bachmann, M.F.; McKall-Faienza, K.; Schmits, R.; Bouchard, D.; Beach, J.; Speiser, D.E.; Mak, T.W.; Ohashi, P.S. Distinct roles for LFA-1 and CD28 during activation of naive T cells: Adhesion versus costimulation. Immunity 1997, 7, 549-557. [CrossRef]

86. Damle, N.K.; Klussman, K.; Aruffo, A. Intercellular adhesion molecule-2, a second counter-receptor for CD11a/CD18 (leukocyte function-associated antigen-1), provides a costimulatory signal for T-cell receptor-initiated activation of human T cells. J. Immunol. 1992, 148, 665-671. [PubMed]

87. Beemiller, P.; Jacobelli, J.; Krummel, M.F. Integration of the movement of signaling microclusters with cellular motility in immunological synapses. Nat. Immunol. 2012, 13, 787-795. [CrossRef] [PubMed]

88. Sims, T.N.; Soos, T.J.; Xenias, H.S.; Dubin-Thaler, B.; Hofman, J.M.; Waite, J.C.; Cameron, T.O.; Thomas, V.K.; Varma, R.; Wiggins, C.H.; et al. Opposing effects of PKCtheta and WASp on symmetry breaking and relocation of the immunological synapse. Cell 2007, 129, 773-785. [CrossRef] [PubMed]

89. Capece, T.; Walling, B.L.; Lim, K.; Kim, K.D.; Bae, S.; Chung, H.L.; Topham, D.J.; Kim, M. A novel intracellular pool of LFA-1 is critical for asymmetric CD8(+) T cell activation and differentiation. J. Cell Biol. 2017, 216, 3817-3829. [CrossRef] [PubMed]

90. Dustin, M.L.; Springer, T.A. T-cell receptor cross-linking transiently stimulates adhesiveness through LFA-1. Nature 1989, 341, 619-624. [CrossRef] [PubMed]

91. Nolz, J.C.; Medeiros, R.B.; Mitchell, J.S.; Zhu, P.; Freedman, B.D.; Shimizu, Y.; Billadeau, D.D. WAVE2 regulates high-affinity integrin binding by recruiting vinculin and talin to the immunological synapse. Mol. Cell Biol. 2007, 27, 5986-6000. [CrossRef] [PubMed]

92. Shimizu, Y.; Van Seventer, G.A.; Horgan, K.J.; Shaw, S. Regulated expression and binding of three VLA (beta 1) integrin receptors on T cells. Nature 1990, 345, 250-253. [CrossRef] [PubMed]

93. Van Seventer, G.A.; Shimizu, Y.; Horgan, K.J.; Luce, G.E.; Webb, D.; Shaw, S. Remote T cell co-stimulation via LFA-1/ICAM-1 and CD2/LFA-3: Demonstration with immobilized ligand/mAb and implication in monocyte-mediated co-stimulation. Eur. J. Immunol. 1991, 21, 1711-1718. [CrossRef] [PubMed]

94. Sedwick, C.E.; Morgan, M.M.; Jusino, L.; Cannon, J.L.; Miller, J.; Burkhardt, J.K. TCR, LFA-1, and CD28 play unique and complementary roles in signaling T cell cytoskeletal reorganization. J. Immunol. 1999, 162, 1367-1375. [PubMed]

95. Zhang, Q.; Dai, H.; Yatim, K.M.; Abou-Daya, K.; Williams, A.L.; Oberbarnscheidt, M.H.; Camirand, G.; Rudd, C.E.; Lakkis, F.G. CD8 ${ }^{+}$Effector T Cell Migration to Pancreatic Islet Grafts Is Dependent on Cognate Antigen Presentation by Donor Graft Cells. J. Immunol. 2016, 197, 1471-1476. [CrossRef] [PubMed]

96. Sutherland, R.M.; Londrigan, S.L.; Brady, J.L.; Carrington, E.M.; Marchingo, J.M.; Heinzel, S.; Hodgkin, P.D.; Graham, K.L.; Kay, T.W.; Zhan, Y.; et al. Cognate antigen engagement on parenchymal cells stimulates CD8(+) T cell proliferation in situ. Nat. Commun. 2017, 8, 14809. [CrossRef] [PubMed] 
97. Ni, H.T.; Deeths, M.J.; Li, W.; Mueller, D.L.; Mescher, M.F. Signaling pathways activated by leukocyte function-associated Ag-1-dependent costimulation. J. Immunol. 1999, 162, 5183-5189. [PubMed]

98. Kanner, S.B.; Grosmaire, L.S.; Ledbetter, J.A.; Damle, N.K. Beta 2-integrin LFA-1 signaling through phospholipase C-gamma 1 activation. Proc. Natl. Acad. Sci. USA 1993, 90, 7099-7103. [CrossRef] [PubMed]

99. Van Seventer, G.A.; Bonvini, E.; Yamada, H.; Conti, A.; Stringfellow, S.; June, C.H.; Shaw, S. Costimulation of $\mathrm{T}$ cell receptor/CD3-mediated activation of resting human $\mathrm{CD}^{+} \mathrm{T}$ cells by leukocyte function-associated antigen-1 ligand intercellular cell adhesion molecule-1 involves prolonged inositol phospholipid hydrolysis and sustained increase of intracellular Ca2 ${ }^{+}$levels. J. Immunol. 1992, 149, 3872-3880. [PubMed]

100. Ni, H.T.; Deeths, M.J.; Mescher, M.F. LFA-1-mediated costimulation of $\mathrm{CD}^{+} \mathrm{T}$ cell proliferation requires phosphatidylinositol 3-kinase activity. J. Immunol. 2001, 166, 6523-6529. [CrossRef] [PubMed]

101. Parameswaran, N.; Suresh, R.; Bal, V.; Rath, S.; George, A. Lack of ICAM-1 on APCs during T cell priming leads to poor generation of central memory cells. J. Immunol. 2005, 175, 2201-2211. [CrossRef] [PubMed]

102. Damle, N.K.; Klussman, K.; Leytze, G.; Aruffo, A.; Linsley, P.S.; Ledbetter, J.A. Costimulation with integrin ligands intercellular adhesion molecule- 1 or vascular cell adhesion molecule-1 augments activation-induced death of antigen-specific CD4 ${ }^{+}$T lymphocytes. J. Immunol. 1993, 151, 2368-2379. [PubMed]

103. Kandula, S.; Abraham, C. LFA-1 on CD4 ${ }^{+} \mathrm{T}$ cells is required for optimal antigen-dependent activation in vivo. J. Immunol. 2004, 173, 4443-4451. [CrossRef] [PubMed]

104. Deeths, M.J.; Mescher, M.F. ICAM-1 and B7-1 provide similar but distinct costimulation for CD8 ${ }^{+} \mathrm{T}$ cells, while CD4 ${ }^{+}$T cells are poorly costimulated by ICAM-1. Eur. J. Immunol. 1999, 29, 45-53. [CrossRef]

105. Chen, T.; Goldstein, J.S.; O’Boyle, K.; Whitman, M.C.; Brunswick, M.; Kozlowski, S. ICAM-1 co-stimulation has differential effects on the activation of $\mathrm{CD}^{+}$and $\mathrm{CD}^{+}$T cells. Eur. J. Immunol. 1999, 29, 809-814. [CrossRef]

106. Shier, P.; Ngo, K.; Fung-Leung, W.P. Defective CD8 ${ }^{+} \mathrm{T}$ cell activation and cytolytic function in the absence of LFA-1 cannot be restored by increased TCR signaling. J. Immunol. 1999, 163, 4826-4832. [PubMed]

107. Makgoba, M.W.; Sanders, M.E.; Ginther Luce, G.E.; Gugel, E.A.; Dustin, M.L.; Springer, T.A.; Shaw, S. Functional evidence that intercellular adhesion molecule-1 (ICAM-1) is a ligand for LFA-1-dependent adhesion in T cell-mediated cytotoxicity. Eur. J. Immunol. 1988, 18, 637-640. [CrossRef] [PubMed]

108. Damle, N.K.; Aruffo, A. Vascular cell adhesion molecule 1 induces T-cell antigen receptor-dependent activation of CD4 ${ }^{+}$T lymphocytes. Proc. Natl. Acad. Sci. USA 1991, 88, 6403-6407. [CrossRef] [PubMed]

109. Snow, A.L.; Pandiyan, P.; Zheng, L.; Krummey, S.M.; Lenardo, M.J. The power and the promise of restimulation-induced cell death in human immune diseases. Immunol. Rev. 2010, 236, 68-82. [CrossRef] [PubMed]

110. Damle, N.K.; Leytze, G.; Klussman, K.; Ledbetter, J.A. Activation with superantigens induces programmed death in antigen-primed $\mathrm{CD}^{+}$class $\mathrm{II}^{+}$major histocompatibility complex $\mathrm{T}$ lymphocytes via a CD11a/CD18-dependent mechanism. Eur. J. Immunol. 1993, 23, 1513-1522. [CrossRef] [PubMed]

111. Yarovinsky, T.O.; Monick, M.M.; Hunninghake, G.W. Integrin receptors are crucial for the restimulation of activated T lymphocytes. Am. J. Respir. Cell Mol. Biol. 2003, 28, 607-615. [CrossRef] [PubMed]

112. Aoudjit, F.; Vuori, K. Engagement of the alpha2beta1 integrin inhibits Fas ligand expression and activation-induced cell death in $\mathrm{T}$ cells in a focal adhesion kinase-dependent manner. Blood 2000, 95, 2044-2051. [PubMed]

113. Stallmach, A.; Giese, T.; Pfister, K.; Wittig, B.M.; Künne, S.; Humphries, M.; Zeitz, M.; Meuer, S.C. Activation of beta(1) integrins mediates proliferation and inhibits apoptosis of intestinal CD4-positive lymphocytes. Eur. J. Immunol. 2001, 31, 1228-1238. [CrossRef]

114. Boggio, E.; Dianzani, C.; Gigliotti, C.L.; Soluri, M.F.; Clemente, N.; Cappellano, G.; Toth, E.; Raineri, D.; Ferrara, B.; Comi, C.; et al. Thrombin Cleavage of Osteopontin Modulates Its Activities in Human Cells In Vitro and Mouse Experimental Autoimmune Encephalomyelitis In Vivo. J. Immunol. Res. 2016, 2016, 9345495. [CrossRef] [PubMed]

115. Rao, W.H.; Hales, J.M.; Camp, R.D. Potent costimulation of effector T lymphocytes by human collagen type I. J. Immunol. 2000, 165, 4935-4940. [CrossRef] [PubMed]

116. Dang, N.H.; Torimoto, Y.; Schlossman, S.F.; Morimoto, C. Human CD4 helper T cell activation: Functional involvement of two distinct collagen receptors, 1F7 and VLA integrin family. J. Exp. Med. 1990, 172, 649-652. [CrossRef] [PubMed] 
117. Matsuyama, T.; Yamada, A.; Kay, J.; Yamada, K.M.; Akiyama, S.K.; Schlossman, S.F.; Morimoto, C. Activation of CD4 cells by fibronectin and anti-CD3 antibody. A synergistic effect mediated by the VLA-5 fibronectin receptor complex. J. Exp. Med. 1989, 170, 1133-1148. [CrossRef] [PubMed]

118. Nojima, Y.; Humphries, M.J.; Mould, A.P.; Komoriya, A.; Yamada, K.M.; Schlossman, S.F.; Morimoto, C. VLA-4 mediates CD3-dependent $\mathrm{CD}^{+} \mathrm{T}$ cell activation via the CS1 alternatively spliced domain of fibronectin. J. Exp. Med. 1990, 172, 1185-1192. [CrossRef] [PubMed]

119. Shimizu, Y.; van Seventer, G.A.; Horgan, K.J.; Shaw, S. Costimulation of proliferative responses of resting $\mathrm{CD}^{+} \mathrm{T}$ cells by the interaction of VLA- 4 and VLA- 5 with fibronectin or VLA- 6 with laminin. J. Immunol. 1990, 145, 59-67. [PubMed]

120. Ybarrondo, B.; O’Rourke, A.M.; McCarthy, J.B.; Mescher, M.F. Cytotoxic T-lymphocyte interaction with fibronectin and vitronectin: Activated adhesion and cosignalling. Immunology 1997, 91, 186-192. [CrossRef] [PubMed]

121. Wagner, C.; Bürger, A.; Radsak, M.; Blum, S.; Hug, F.; Hänsch, G.M. Fibronectin synthesis by activated T lymphocytes: Up-regulation of a surface-associated isoform with signalling function. Immunology 2000, 99, 532-539. [CrossRef] [PubMed]

122. Blum, S.; Hug, F.; Hänsch, G.M.; Wagner, C. Fibronectin on activated T lymphocytes is bound to gangliosides and is present in detergent insoluble microdomains. Immunol. Cell Biol. 2005, 83, 167-174. [CrossRef] [PubMed]

123. Adler, B.; Ashkar, S.; Cantor, H.; Weber, G.F. Costimulation by extracellular matrix proteins determines the response to TCR ligation. Cell. Immunol. 2001, 210, 30-40. [CrossRef] [PubMed]

124. Hibino, S.; Kato, K.; Kudoh, S.; Yagita, H.; Okumura, K. Tenascin suppresses CD3-mediated T cell activation. Biochem. Biophys. Res. Commun. 1998, 250, 119-124. [CrossRef] [PubMed]

125. Bergström, S.E.; Uzunel, M.; Talme, T.; Bergdahl, E.; Sundqvist, K.G. Antigen-induced regulation of T-cell motility, interaction with antigen-presenting cells and activation through endogenous thrombospondin-1 and its receptors. Immunology 2015, 144, 687-703. [CrossRef] [PubMed]

126. Miller, T.W.; Kaur, S.; Ivins-O'Keefe, K.; Roberts, D.D. Thrombospondin-1 is a CD47-dependent endogenous inhibitor of hydrogen sulfide signaling in T cell activation. Matrix Biol. 2013, 32, 316-324. [CrossRef] [PubMed]

127. Li, Z.; Calzada, M.J.; Sipes, J.M.; Cashel, J.A.; Krutzsch, H.C.; Annis, D.S.; Mosher, D.F.; Roberts, D.D. Interactions of thrombospondins with alpha4beta1 integrin and CD47 differentially modulate $\mathrm{T}$ cell behavior. J. Cell. Biol. 2002, 157, 509-519. [CrossRef] [PubMed]

128. Ashkar, S.; Weber, G.F.; Panoutsakopoulou, V.; Sanchirico, M.E.; Jansson, M.; Zawaideh, S.; Rittling, S.R.; Denhardt, D.T.; Glimcher, M.J.; Cantor, H. Eta-1 (osteopontin): An early component of type-1 (cell-mediated) immunity. Science 2000, 287, 860-864. [CrossRef] [PubMed]

129. Siokis, A.; Robert, P.A.; Meyer-Hermann, M. Mathematical Modeling of Synaptic Patterns. Methods Mol. Biol. 2017, 1584, 171-182. [CrossRef] [PubMed]

130. Sun, M.; Zaman, M.H. Modeling, signaling and cytoskeleton dynamics: Integrated modeling-experimental frameworks in cell migration. Wiley Interdiscip. Rev. Syst. Biol. Med. 2017, 9. [CrossRef] [PubMed]

(c) 2018 by the authors. Licensee MDPI, Basel, Switzerland. This article is an open access article distributed under the terms and conditions of the Creative Commons Attribution (CC BY) license (http:/ / creativecommons.org/licenses/by/4.0/). 